\title{
STATUS GIZI IBU HAMIL DAPAT MENYEBABKAN STUNTING
}

\author{
Faradila Guhir
}

Universitas Islam Negeri Alauddin Makassar

Email : faradilaguhir@gmail.com

\section{PENDAHULUAN}

Permasalahan gizi harus diperhatikan sejak masih dalam kandungan. Riwayat status gizi ibu hamil menjadi faktor penting terhadap keadaan kesehatan dan perkembangan janin. Gangguan pertumbuhan dalam kandungan dapat menyebabkan berat badan lahir rendah yang berisiko mengalami stunting (WHO, 2014).

Stunting adalah kondisi dimana balita memiliki panjang atau tinggi badan yang kurang jika di bandingkan dengan anak seusianya. Kondisi ini diukur dengan panjang atau tinggi badan yang lebih dari mines 2 standar devisi (sd) median standar pertumbuhan anak dari world health organization. Balita stunting termasuk masalah gizi kronik yang disebabkan oleh banyak faktor seperti kondisi sosial ekonomi, gizi ibu saat hamil, dan kurangnya asupan gizi pada bayi. Balita stunting dimasa yang akan datang akan mengalami kesulitan dalam mencapai perkembangan fisik dan kognitif yang optimal.

Indikator stunting menurut World health organization adalah jika prevalensi balita pendek mencapai $20 \%$ atau lebih.Berdasarkan data terdapat $22,2 \%$ balita stunting atau sekitar 150,8 juta balita didunia mengalami stunting. Angka ini sudah mengalami penurunan jika dibandingkan dengan angka stunting pada tahun 2000 yaitu 32,6\%. Pada tahun yang sama, lebih dari setengah balita Stunting didunia berasal dari asia (55\%) sedangkan lebih dari sepertiganya (39\%) tinggal di Afrika, dari 83,6 juta balita stunting di Asia proporsi terbanyak berasal dari asia selatan $(58,7 \%)$ (Riskesdes,2017)

Angka kejadian stunting di Indonesia adalah (30,8\%), jika dibandingkan tahun 2013 (37,2\%) dan tahun 2007 (36,8\%). Proporsi teratas 2018 adalah NTT dan SULBAR (42,6\%), Sumatera Utara (30,8\%) serta terendah adalah DKI Jakarta (17,7\%) (Riskesdas, 2017).Berdasarkan pamantauan status Gizi di Sulawesi Selatan persentasi pendek dan sangat 
pendek pada balita 0-23 bulan tercatat sebesar 21,8\%. Angka tersebut terdiri dari 6,1\% masuk kategori sangat pendek dan 15,7\% dikategori pendek (Kemenkes 2018).

Riwayat status gizi ibu selama hamil dapat diketahui dengan melihat ukuran pertambahan berat badan trisemester III dengan pertumbuhan anak berdasarkan berat badan terhadap umur, tinggi badan terhadap umur serta berat badan terhadap tinggi badan. Di Indonesia, salah satu parameter untuk menentukan status gizi ibu hamil adalah Indikator antropometri Lingkar Lengan Atas (LiLA) pada ibu, dimana asupan energi dan protein yang tidak mencukupi pada ibu hamil dapat menyebabkan Kurang Energi Kronis (KEK). Wanita hamil berisiko mengalami KEK jika memiliki Lingkar Lengan Atas (LILA).

Faktor resiko terjadinya stunting antara lain, status gizi ibu hamil terhadap pertumbuhan dan perkembangan janinnya, dimana permasalahan gizi harus diperhatikan sejak masih dalam kandungan. Jika terjadi kekurangan status gizi awal kehidupan maka akan berdampak terhadap kehidupan selanjutnya seperti Pertumbuhan Janin Terhambat (PJT), Berat Badan Lahir Rendah (BBLR), kecil, pendek, kurus, daya tahan tubuh rendah dan risiko meninggal dunia.

\section{Hubungan Status Gizi Ibu Saat Hamil dengan Stunting}

Status gizi atau tingkat konsumsi pangan merupakan bagian terpenting dari status kesehatan seseorang. Tidak hanya status gizi yang mempengaruhi kesehatan seseorang, tetapi status kesehatan juga mempengaruhi status gizi. Kondisi ibu hamil, bahkan sebelum hamil akan menentukan pertumbuhan janin. Ibu hamil yang kekurangan gizi akan berisiko melahirkan bayi dengan berat lahir rendah, dan ini merupakan penyebab utama. Setelah lahir, bayi yang tidak disusui secara baik akan berisiko menderita berbagai infeksi penyakit karena pola makan yang tidak cukup asupan gizinya dan tidak higienis. Pemberian Makanan Bayi dan Anak sangat menentukan pertumbuhan anak. Setelah usia 6 bulan anak perlu mendapat asupan gizi dapat memenuhi kebutuhan asupan gizi mikro, gizi makro serta aman.

Kondisi kesehatan dan status gizi ibu saat hamil dapat mempengaruhi pertumbuhan dan perkembangan janin. Ibu yang mengalami kekurangan energi kronis atau anemia selama kehamilan akan melahirkan bayi dengan berat badan lahir rendah (BBLR). Berat lahir rendah banyak dihubungkan dengan tinggi badan yang kurang atau stunting.Oleh karena itu 
diperlukannya upaya pencegahan dengan menetapkan dan/atau memperkuat kebijakan untuk meningkatkan intervensi gizi ibu.

Gizi ibu hamil perlu mendapat perhatian karena sangat berpengaruh pada perkembangan janin yang dikandungnya. Sejak janin sampai anak berumur dua tahun atau 1000 hari pertama kehidupan kecukupan gizi sangat berpengaruh terhadap perkembangan fisik dan kognitif. Pada masa kehamilan gizi ibu hamil harus memenuhi kebutuhan gizi untuk dirinya dan untuk pertumbuhan serta perkembangan janin karena gizi janin tergantung pada gizi ibu dan kebutuhan gizi ibu juga harus tetap terpenuhi (Kemenkes RI, 2016)

\section{Masalah Gizi Ibu Hamil}

\section{Kekurangan Energi Kronis (KEK)}

Pada ibu hamil yang terdeteksi mengalami KEK maka upaya yang dapat dilakukan adalah menambah porsi makanan lebih banyak atau lebih sering dari kebiasaan sebelum hamil dan istirahat lebih banyak, serta melakukan pemeriksaan antenatal care secara teratur untuk memantau peningkatan berat badan yang adekuat. Ibu harus makan satu porsi lebih banyak daripada biasanya dan minum minimal 8 gelas sehari (1,5 liter sampai 2,0 liter). Ibu hamil juga diberikan makanan tambahan dengan nilai kalori $500 \mathrm{kkal}$ dan 17 gram protein setiap hari selama minimal 3 bulan (90 hari), istirahat yang cukup pada siang hari serta perlu adanya konseling gizi oleh tenaga kesehatan kepada ibu hamil KEK dan keluarganya untuk menanamkan pengertian, memperbaiki sikap dan perilaku sehat bagi ibu, keluarga dan masyarakat di lingkungan tempat tinggalnya (Kemenkes, 2013).

\section{Anemia}

Ibu hamil sering terjadi anemia defisiensi zat besi sehingga hanya memberi sedikit besi kepada janin yang dibutuhkan untuk metabolism besi yang normal, ibu hamil akan menjadi anemia jika kadar hemoglobin turun sampai dibawah $11 \mathrm{gr} / \mathrm{dl}$ selama trisemester III.

\section{Risiko BBLR}

Kenaikan berat badan rendah selama hamil cenderung melahirkan bayi BBLR Bila bayi lahir BBLR akan mengalami risiko kematian, gizi kurang, gangguan pertumbuhan dan gangguan perkembangan anak. 


\section{Ciri-ciri anak Stunting}

1. Pertumbuhan melambat.

2. Wajah tampak lebih muda dari usianya.

3. Pertumbuhan gigi terlambat.

4. Performa buruk pada tes perhatian dan memori belajar.

5. Tanda pubertas terlambat

\section{Dampak dari Stunting}

Dampak stunting umumnya terjadi disebabkan kurangnya asupan nutrisi pada 1.000 hari pertama anak. Hitungan 1.000 hari di sini dimulai sejak janin sampai anak berusia 2 tahun, Jika pada rentang waktu ini, gizi tidak dicukupi dengan baik, dampak yang ditimbulkan memiliki efek jangka pendek dan efek jangka panjang:

1. Dampak yang muncul dalam jangka pendek

Anak yang mengalami stunting dampak yang muncul dalam jangka pendek yaitu terganggunya perkembangan otak, kecerdasan, gangguan pertumbuhan fisik, dan gangguan metabolisme dalam tubuh.

2. Dampak yang muncul dalam jangka panjang Dalam jangka panjang akibat buruk yang dapat ditimbulkan stunting adalah menurunnya kemampuan kognitif dan prestasi belajar, menurunnya kekebalan tubuh sehingga mudah sakit, dan resiko tinggi untuk munculnya penyakit diabetes, kegemukan, penyakit jantung dan pembuluh darah, kanker, stroke, dan disabilitas pada usia tua.

\section{Pencegahan Stunting}

Pencegahan Stunting bisa dilakukan dengan cara-cara berikut ini :

1. Berikan anak gizi seimbang agar tubuhnya bisa bertambah tinggi dan untuk perkembangan otak anak.

2. Melakukan aktivitas fisik, minimal olah raga 30 menit setiap hari.

3. Jangan biarkan anak tidur larut malam agar anak mendapat istirahat yang cukup.

Upaya pencegahan baiknya dilakukan sedini mungkin. Pada usia 1.000 hari pertama kehidupan, asupan nutrisi yang baik sangat dianjurkan dikonsumsi oleh ibu hamil, Tidak hanya 
untuk mencukupi kebutuhan nutrisi dirinya, asupan nutrisi yang baik juga dibutuhkan jabang bayi yang ada dalam kandungannya,pada saat bayi telah lahir, konsumsi protein sangat mempengaruhi pertambahan tinggi dan berat badan anak di atas 6 bulan, Anak yang mendapat asupan protein 15 persen dari total asupan kalori yang dibutuhkan terbukti memiliki badan lebih tinggi dibanding anak dengan asupan protein 7,5 persen dari total asupan kalori Anak usia 6 sampai 12 bulan dianjurkan mengonsumsi protein harian sebanyak $1,2 \mathrm{~g} / \mathrm{kg}$ berat badan. Sementara anak usia 1-3 tahun membutuhkan protein harian sebesar $1,05 \mathrm{~g} / \mathrm{kg}$ berat badan. 


\section{DAFTAR PUSTAKA}

Adha, A. S., Bahtiar, N. W., Ibrahim, I. A., Syarfaini, S., \& Nildawati, N. (2021). Analisis Hubungan Pola Asuh Ibu Dengan Kejadian Stunting Pada Balita Di Kabupaten Jeneponto. Al GIZZAI: PUBLIC HEALTH NUTRITION JOURNAL, 1(2), 71-82.

Sumardi Sudarman, Aswadi, M. S., \& Gabut, M. (2021). Faktor Yang Berhubungan Dengan Kejadian Stunting Pada Balita di Wilayah Kerja Puskesmas Pannambungan Kota Makassar. Public Health Nutrition Journal, 1(1), 1-15.

Ibrahim, I. A., Alam, S., Adha, A. S., Jayadi, Y. I., \& Fadlan, M. (2021). Hubungan Sosial Budaya Dengan Kejadian Stunting Pada Balita Usia 24-59 Bulan Di Desa Bone-Bone Kecamatan Baraka Kabupaten Enrekang Tahun 2020. Public Health Nutrition Journal, 1(1), 16-26.

Arini, D., Fatmawati, I., Ernawati, D., \& Berlian4, A. (2020). Hubungan Status Gizi Ibu Selama

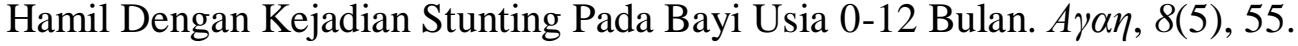

Alfarisi, R., Nurmalasari, Y., \& Nabilla, S. (2019). Status Gizi Ibu Hamil Dapat Menyebabkan Kejadian Stunting Pada Balita. Jurnal Kebidanan Malahayati, 5(3), 271-278.

Nainggolan, R. (2019). Pengaruh Faktor Ibu dan Anak Terhadap Kejadian Stunting Pada Anak Usia 24-36 Bulan di Kabupaten Serdang Bedagai. 3-3.

Berlian, A. (2019). Hubungan Status Gizi Ibu Selama Hamil Dengan Kejadian Stunting Pada Bayi Usia 0-12 Bulan Di Wilayah Kerja Puskesmas Kenjeran Surabaya

Kementrian Kesehatan RI. (2018). Cegah Stunting, itu Penting. Pusat Data Dan Informasi, Kementerian Kesehatan RI, 1-27. 